\title{
Real Options and Foreign Affiliate Divestments: A Portfolio Perspective
}

\author{
René Belderbos \\ Katholieke Universiteit Leuven, Department of Managerial Economics, Strategy and \\ Innovation, Leuven, Belgium
}

\author{
Jianglei Zou \\ Fortis Bank N.V., Brussels, Belgium
}

\section{Addresses:}

Prof. Dr. René A. Belderbos, Katholieke Universiteit Leuven, Department of Managerial Economics, Strategy and Innovation, Naamsestraat 69 ,B-3000 Leuven, Belgium. Phone + 32 16 326912; Fax + 3216 326732; Email: Rene.belderbos@econ.kuleuven.be

Dr. Jianglei Zou, Fortis Bank N.V., Merchant \& Private Banking Strategy, Warandeberg 3, 1000 Brussels, Belgium. Phone +32 256550 10; Fax +32 256515 99; Email:

jianglei.zou@fortis.com

\begin{abstract}
This paper develops a real options portfolio perspective on foreign affiliate divestments. Affiliates are less likely to be divested in response to adverse environmental change if they represent growth or switch option value to the multinational firm under conditions of macroeconomic uncertainty. However, the affiliate is partially redundant to the option value of the multinational firm's affiliate portfolio if the affiliate shares the manufacturing platform role in the host country with other affiliates, or if macroeconomic conditions of the host country are highly correlated with those of other countries in which the multinational firm operates affiliates. We find strong support for these arguments in tests on a comprehensive sample of 1078 Asian manufacturing affiliates of Japanese electronics multinationals.
\end{abstract}

\section{Acknowledgements}

This paper benefited from helpful comments by Sea-Jin Chang, three anonymous referees, Ilja Cuypers, Koen De Backer, Victor Gilsing, Jean Francois Hennart, Xavier Martin, Leo Sleuwaegen, Reinhilde Veugelers, and participants at the Korea and World Economy Conference in Seoul, the Ninth International Convention of the East Asian Economic Association in Hong Kong, the Annual conference on Corporate Strategy at WHU-Vallendar, the Annual conference of the Academy of International Business (AIB), and seminars at the Katholieke Universiteit Leuven, Tilburg University and Keio University. 


\section{Introduction}

One of the advantages of multinational firms is their ability to hedge risks through their presence in multiple countries with diverse market dynamics and cost developments. Multinational firms, in particular those that are active in global industries, can actively exploit the flexibility that a portfolio of multinational affiliates provides by shifting value added activities internationally between affiliates in response to such divergent cost and market developments. Real option theory conceptualizes how operating manufacturing plants in different countries can create value for the multinational firm by providing growth and flexibility options under uncertainty concerning future macroeconomic and policy conditions (e.g. Kogut and Kulatilaka, 1994a; Li and Rugman, 2005). However, empirical research in this area has provided ambiguous results concerning the market valuation and downside risk implications of multinational operations (e.g. Reuer and Leiblein, 2000; Tong and Reuer, 2007; Tang and Tikoo, 1999). Recent studies have suggested that this may be related to the heterogeneous contribution of affiliates to multinational firms' option values. Tong, Reuer, and Peng (2008) find that the value of firms' growth options is most enhanced by minority-owed joint ventures in non-core lines of business, while Tong et al. (2008) suggest differences in option valuation due to home country and industry characteristics. Tong and Reuer (2007) find that the relationship between multinationality and downside risk is U-shaped. They argue that with higher dispersion of affiliates, their marginal benefits are likely to decrease while the marginal costs of coordination and utilization of switch options may increase.

In this paper, we argue that an explanation of heterogeneity in the real option value of multinationality should encompass a portfolio perspective on real options. In a portfolio perspective, growth or switch option value of the multinational firm's portfolio of foreign affiliates can be smaller than the sum of the option values of its individual foreign affiliates. Affiliates are sub-additive to the portfolio or (partially) redundant from an options portfolio perspective if the characteristics of their options overlap with those of other affiliates. This situation occurs if an affiliate shares a manufacturing platform role in the host country with other affiliates, or if macroeconomic conditions of the host country are highly correlated with those of other countries in which the multinational firm 
operates affiliates. In this perspective, it is not just the degree of multinationality that matters, but also the configuration of foreign affiliates in terms of the distribution over host countries and the macroeconomic characteristics of these host countries. The relevance of a portfolio perspective on real options has been examined previously in the context of R\&D projects and alliance strategies. Prior studies have suggested that real option values are reduced if $R \& D$ investments or alliances have similar, correlated, performance characteristics (e.g. Vassolo et al., 2004; Girortra et al., 2006).

In this paper, we examine the role of real option portfolios in the context of foreign affiliate divestment decisions. Affiliate divestments are important strategic decisions by multinational firms, but divestment decisions have received relatively little systematic attention in the literature. ${ }^{1}$

Divestments are a fruitful testing ground for real options theory as option value can be assessed from the degree of 'investment hysteresis': the reluctance of multinational firms to divest affiliates in response to adverse circumstances under conditions of uncertainty The analysis explicitly takes into account that the option value of an affiliate is a function of redundancies within the portfolio of affiliates operated by the multinational firm, both within the host country and at the international level.

We test the predictions derived from real options theory on a comprehensive sample of 1078 manufacturing affiliates operated in nine Asian countries by Japanese electronics multinationals during the years preceding and into the Asian financial crisis (1995-1998). This is an interesting setting for our analysis from several perspectives. Multinational firms operating in Asia in these years faced great uncertainty concerning exchange rates, inflation, and economic recovery and demand, while future growth opportunities in these emerging economies are important. This suggests that the option value of operating affiliates in various countries would have been substantial.

\section{Theory and Hypotheses}

Real options theory conceptualizes how foreign affiliate investments can add value to multinational firms in the context of uncertainty concerning future international market, cost, and policy conditions. Two related types of options have been emphasized in the literature. Kogut and Kulatilaka (1994b) suggest that foreign investments can effectively serve as a 'platform' for future 
expansion, creating growth options that the multinational firm otherwise would not be able to obtain. Early investments in manufacturing operations in a country allows the multinational firm to learn about the country environment, build up relationships with local suppliers, customers and government institutions, adapt products and processes to the local circumstances, and generally reduce their 'liability of foreignness' (Song, 2002; Belderbos et al, 2001; Chang, 1995). In case the opportunities for expansion materialize and uncertainty is resolved, the platform investment facilitates a quick expansion of operations in the country through sequential investments. The value of the growth option embedded in the platform investment is higher the greater the degree of uncertainty concerning the future operating environment in the country. It is typically higher in emerging markets with higher 'upside' growth potential that coincides with greater macroeconomic and policy uncertainty. The growth option of the platform investment can be seen as an additional part of affiliate value on top of the net present value valuation (Trigeorgis, 1993; Vassolo et al., 2004). Kogut and Chang (1996) provide empirical evidence for Japanese investors in the United States that firms with initial investments are more likely to take follow up investment decisions, in particular when exchange rate developments are favourable. ${ }^{2}$

A second and related real option arises because foreign manufacturing affiliates are part of a configuration of domestic and foreign plants, and contribute to the options to switch manufacturing operations quickly between locations in response to changing cost differentials and market opportunities. Kogut and Kulatilaka (1994a) theoretically derived the option value of this operational flexibility to adjust capacity loadings of affiliate operations in various countries as depending on the uncertainty concerning manufacturing cost differentials. Multinational firms can benefit from keeping options of future manufacturing expansion open in various countries with potentially divergent macroeconomic developments. The literature on multinationality and firm performance has emphasized that multinational firms can achieve lower operational costs by adapting manufacturing plant networks to changing cost and demand conditions in multiple countries, which is likely to improve firm value (Gomes and Ramaswamy, 1999; Tang and Tikoo, 1999). Several studies have confirmed that multinational firms adjust operations of affiliates in response to changes in relative cost and market conditions. Rangan (1998) finds that changes in exchange rate movements lead to shifts in 
manufacturing and intra-firm imports of affiliates operated by US multinational firms. Belderbos and Zou (2007) find evidence of employment shifts between plants operated by Japanese firms in Asia in response to differential labor cost movements. ${ }^{3}$

The real option value of foreign affiliate investments has specific consequences for the decision whether or not to divest these affiliates. Under uncertainty concerning future macroeconomic circumstances, firms will not immediately resort to divestment if affiliates are poorly performing due to an adverse macroeconomic shock. Given that foreign affiliate divestments are partly irreversible (i.e. the value of investments cannot be (fully) recouped through sale of assets in case of withdrawal ${ }^{4}$ ) and that rebuilding investment positions is costly and time consuming, maintaining affiliate investment positions provides option value under uncertainty. The reluctance to divest affiliates is greater, the greater the degree of uncertainty. A similar real options logic has been formally demonstrated in Kouvelis et al. (2001) in the context of foreign affiliate investment vs. export decisions. In the presence of switching costs (partial irreversibility) between the two market entry options, uncertainty creates inertia in the strategic response to a relevant macroeconomic change (i.e. a change in the real exchange rate) affecting the underlying profitability of the entry options. Uncertainty causes that initial decisions are not reversed even if environmental changes adversely affect the profitability of the strategy chosen and would call for a change in strategy. This phenomenon of inertia is labeled 'hysteresis'. It is important to note that real options theory applied to changes in foreign investment strategies does not predict that uncertainty as such reduces the probability of adapting investment positions: the value of real options only manifests itself if there is an initial trigger for strategic change. Hence, uncertainty moderates firms' responsiveness to adverse shocks affecting investment performance but is not predicted to impact divestment decisions without such a trigger. In the context of foreign divestment decisions, real option theory suggests that the option value created by macroeconomic uncertainty combined with a partial irreversibility of investments can reduce the responsiveness to adverse macroeconomic shocks and create 'investment hysteresis'. The greater the uncertainty concerning future growth and cost development prospects of the affiliate, the more firms value the flexibility of keeping growth and switching options open, and the less likely it is that 
affiliates are divested in response to adverse changes in the environment. This leads to the following hypothesis:

Hypothesis 1 (Hysteresis): The impact of adverse environmental changes in a host country on the probability of divestment is smaller for affiliates in host countries characterized by greater macroeconomic uncertainty.

Multinational firms operating a network of affiliates in various countries maintain a portfolio of growth and switch options, and assess investments, divestments and option values at the portfolio level rather than for individual affiliates in isolation. This implies a qualification of the option value of individual affiliates, as the option value of the network of affiliates is not identical to the sum of the option values of the different affiliates. It has been pointed out that if firms possess portfolios of real options, the values of these individual options may not be additive (McGrath, 1997). ${ }^{5}$ If the growth or switch options overlap or duplicate each other due to correlations in uncertainty profiles and expected outcomes, the option value of the portfolio is reduced (Vassolo et al, 2004; Girortra et al., 2006). In such cases, the growth or switch option of affiliate A is partly captured by affiliate $\mathrm{B}$, hence investments in A and B are partly redundant or sub-additive from an options valuation perspective. The concept of sub-additivity has been developed in the work of Milgrom and Roberts (1990) in the context of optimal design of organisational practices. ${ }^{6}$ If $\mathrm{V}$ denotes the option value of an affiliate portfolio, subadditivity of options $\mathrm{A}$ and $\mathrm{B}$ is defined as $\mathrm{V}(\mathrm{B}, \mathrm{A})-\mathrm{V}(\mathrm{A})<\mathrm{V}(\mathrm{B})+\mathrm{V}(0)$, or $\mathrm{V}(\mathrm{B}, \mathrm{A})<$ $\mathrm{V}(\mathrm{A})+\mathrm{V}(\mathrm{B})$. Adding option $\mathrm{B}$ to a portfolio containing option A leads to a smaller increase in the option value of the portfolio compared to adding option B to a portfolio not containing option A. Hence, a portfolio with both options A and B included has a lower real option value than the sum of two portfolios including only option A and option B, respectively. Hence, affiliates contribute less option value to the firm if their option characteristics are partly redundant in the portfolio. The real option value of an affiliate for a multinational firm can only be assessed accurately by taking into account the configuration of real options captured by the portfolio of affiliates.

In the context of multinational plant portfolios, two dimensions of redundancy or sub- 
additivity can be distinguished: at the host country level and at the multinational portfolio level. At the host country level, a distinction has to be made between an affiliate that is the only affiliate of the firm in a country: i.e. it effectively serves as the country 'platform' that embeds option value; and an affiliate that is one of more affiliates operated by the firm in the country ('non-platform' affiliates). The option value attributed to non-platform affiliates is smaller, as another affiliate can duplicate the platform role and each can potentially serve as an instrument for future expansion. This implies that investment 'hysteresis', the process of investment inertia under macroeconomic uncertainty, is weaker for affiliates that are redundant from the host country perspective.

Hypothesis 2 (Host Country Redundancy): The hysteresis effect is smaller for host country redundant affiliates: affiliates that are not the only manufacturing affiliate of the firm in a host country.

The second dimension of the affiliate portfolio of multinational firms is the configuration of plants across countries with varying macroeconomic uncertainty profiles. The configuration of the multinational portfolio of affiliates determines the switching option value of an individual affiliate in the portfolio. An affiliate represents less additive option value to the multinational firm, if the characteristics of its real options are overlapping with those of affiliates in other countries. The switch options of the affiliates can overlap or duplicate each other due to correlations in uncertainty profiles and expected outcomes. A similar argument has been tested in the context of alliances (Vassolo et al., 2004) and R\&D projects (Girortra et al., 2006). In the context of switch options in multinational firms' configurations of foreign affiliates, the potential overlap in switch options between an affiliate in country A and an affiliate in country B is a function of the correlation between the relevant macroeconomic changes in the two countries, as cost reduction or growth opportunities are expected to arise in both countries at the same time. The switch option value of an affiliate portfolio is higher, the greater the variety of macroeconomic developments in the countries in which the affiliates are established. In contrast, if two countries represented in the portfolio have non-divergent macroeconomic developments, the option values of affiliates established in these countries are sub- 
additive and the affiliates can be seen as redundant to the multinational firm's portfolio. ${ }^{7}$ The greater the degree of real option redundancy of an affiliate within the portfolio, the smaller is its contribution to the portfolio's option value, and the weaker the incentives of the multinational firm to maintain manufacturing operations even under adverse macroeconomic circumstances. Hence, the 'hysteresis' effect due to real option valuation of affiliates is weakened. This leads to the following hypothesis:

\author{
Hypothesis 3 (Multinational Portfolio Redundancy): The hysteresis effect is smaller for \\ affiliates exhibiting a high degree of multinational portfolio redundancy: affiliates located in a \\ country of which macroeconomic environmental change is highly correlated with other \\ countries in which the multinational firm operates affiliates.
}

\title{
3. Data and Empirical Methods
}

\section{Data}

Our dataset consists of the population of 1095 manufacturing affiliates operational in early 1995 that were wholly or partially controlled by 412 Japanese firms in the broadly defined electronics industry in 9 Asian countries or regions, i.e. South Korea, Taiwan, China, Hong Kong, Singapore, Indonesia, Philippines, Malaysia, and Thailand. The data are compiled by the Research Institute of Electronic Industry as "Asia Shinshutsu Denshi Meika" (Survey of Japanese electronic firms in Asia) in Tokyo in 1995 and early 1999. It is an authoritative source on Japanese foreign investments in Asia in the electronics industry with complete coverage of investments by both large firms, small and medium sized firms, and specialized suppliers to the electronics industry (glass, plastic, metals, chemical materials). ${ }^{8}$ The data provide a detailed picture of investments by both leading electronics firms and suppliers along the value chain of the electronics industry. The database contains information on the affiliates' paid-in capital, number of employees, equity stake held by Japanese investors, and products manufactured, and it also contains parent firm information on sales, number of employees, paid-in capital, and recent developments in the firms' overseas operations. A divestment case was identified if we could confirm that a 1995 manufacturing affiliate was either closed or its 
stake sold to a local or foreign firm by its parent within the 1995-1998 period. The confirmation was given by the parent information provided for each Japanese firm on such decisions in the 1999 edition of the survey, combined with information from other publications by the Research Institute of Electronics Industry on developments in Japanese electronics firms (such as quarterly compilations of press releases), other sources on Japanese affiliates abroad (Toyo Keizai, various issues), and coverage in Japanese newspapers drawn from the Nikkei web news service. As a result, 99 out of 1095 overseas manufacturing affiliates in operation in 1995 were identified as having been divested by early 1999 . Since for 17 affiliates a number of explanatory variables (primarily parent sales and affiliate employment) had missing values, our empirical analysis is performed on 1078 affiliates of 408 parent firms, out of which 97 are divestment cases. China had the largest share of affiliates in our sample (22 percent), followed by Malaysia (21) and Taiwan (13). Divestments were most frequent in Singapore, with 19 percent of affliates divested in the period, followed by Hong Kong (16), and South Korea (14).

\section{Model specification}

Our dependent variable is binary, taking the value 1 if a 1995 affiliate is divested prior to early 1999 and 0 if it survived as a parent affiliate in the 1995-1998 period. We use a probit model to relate the probability of divestment to the explanatory variables (e.g. Greene, 1997). In order to control for a potential lack of independence between the error terms of affiliates belonging to the same parent firm, we cluster error terms at the level of the parent (e.g. Barkema and Shvyrkov, 2006), in addition to including a range of parent-level control variables. We use a discrete choice model rather than a duration model. As we were only able to determine the exact year of the divestments for about half (48) of the divestment cases, a duration analysis would diminish the representativeness of analysis substantially. In order to analyze the robustness of the results with respect to duration analysis, we present the results of a Cox proportional hazard model with yearly varying covariates in Appendix B and report on these in the last paragraph of section $4 .{ }^{9}$

\section{Operational measures}

To test Hypothesis 1, we need to select a relevant measure of macroeconomic uncertainty in a 
country as well as a relevant measure of adverse macroeconomic circumstances. We follow Kouvelis et al. (2001) in taking the movements in the host countries' real exchange rate as the main source of macroeconomic uncertainty. Several studies have established an important impact of host country exchange rate changes on (foreign) investment decisions (Froot and Stein, 1991; Campa and Goldberg, 1997). Uncertainty is the coefficient of variation of the monthly real exchange rate of the local currency against the Yen during 1995-1998. In the context of international manufacturing operations and global industries, the most relevant indicator of adverse macroeconomic circumstances is an increase in real labor costs. This follows the logic of real options theory and multinational plant configurations, in which cost minimization is the primary objective (Kogut and Kulatilaka, 1994a). ${ }^{10}$ Other empirical studies have established that this measure has an important impact on affiliate growth and international relocation of manufacturing activities, (e.g. Belderbos and Zou, 2007). We include labor cost growth, the percentage growth in the monthly wages (expressed in Yen) of manufacturing workers in the host country's electronics industry between 1995 and 1998. Using the Yen denominated wage cost controls for the effects of exchange rate movements and inflation. Hypothesis 1 predicts a positive impact of adverse environmental changes (measured as labor cost growth) on divestment, which is moderated by macroeconomic uncertainty. This implies a negative interaction term of labor cost growth and uncertainty. To examine the exact moderation effect, however, we cannot solely rely on the value and significance of the interaction coefficient, but we have to calculate the cross derivative and its significance (e.g. Ai and Norton, 2003).

Hypothesis 2 suggests a differential impact of hysteresis on affiliates that are redundant from a host country perspective (non-platform affiliates) and affiliates that are non-redundant (platform affiliates). We test for such differential impact on divestment by performing split-sample analysis, one for platform affiliates and one for non-platform affiliates. Platform affiliates are affiliates in a host country in which the parent firm did not operate other manufacturing affiliates in 1995 . The hysteresis effect is expected to be strong for such platform affiliates, but weak for non-platform affiliates that are redundant from a host country perspective. We performed a split sample test rather than including a further interaction term with the hysteresis effect, as a split sample analysis is the more general test specification when comparing coefficients between groups (Hoetker, 2007). A split sample test does 
not assume that unexplained variance is identical between the two groups of affiliates and also allows that the impact of other affiliate characteristics differs systematically between the groups, leading to consistent within-group estimates.

To test hypothesis 3 we calculated a measure of the correlation of the real exchange rate changes between the country of the affiliate and the other Asian countries in which the multinational firm operated manufacturing affiliates. We took the sum of the correlations of the monthly real exchange rate of the country of investment and the other countries in which the multinational operated manufacturing plants in $1995 .{ }^{11}$ We use real exchange rate correlations rather than real labor cost correlations as only the former are available on a monthly basis to establish meaningful correlation coefficients. A high correlation indicates a greater likelihood that future changes in macroeconomic conditions, such as labor cost changes caused by exchange rate developments, develop in a parallel manner without substantial opportunities to exploit country differences. ${ }^{12}$ We sum over a maximum of 8 (other) Asian countries, for which we can depict exact affiliate portfolios for all the firms. The restriction to the Asian manufacturing operations of the Japanese electronics firms is a limitation. Yet it provides a good testing ground as previous research (e.g. Belderbos and Sleuwaegen, 2006; Ernst, 1997) has suggested that Japanese firms configure and coordinate the production in Asian affiliates in particular in a systematic and integrated manner, and that relocations occur frequently between Asian manufacturing operations but not from Asia to other regions. In other words, considerations of redundancy as well as actual use of switching options are likely to be most relevant within the region. The variable multinational portfolio correlation ranges between zero and $5.17 .{ }^{13}$ Hypothesis 3 predicts that affiliates characterized by high multinational portfolio correlation have a reduced switching option value: hence the hysteresis effect is predicted to be small. We split the sample based on the empirical values of the multinational portfolio correlation, taking the median multinational portfolio correlation as the focal point. High network redundancy affiliates are those affiliates with above median (1.10) values of multinational portfolio correlation. ${ }^{14}$

\section{Control variables}

The model includes an extensive set of control variables representing factors at the parent, 
affiliate, and host country level suggested to have a potential impact on divestment in earlier studies.

We include a number of parent-level control variables. Parent firm patent intensity (the number of US patents granted to the parent firm during 1993-1999 times 1000, divided by parent sales in 1995). Patent intensity proxies for competitive advantages based on advanced technology that are likely to increase the probability of affiliate survival. Furthermore, we include parent size. This variable has been found to impact the probability of divestment positively (Li, 1995; Hennart et al., 1998; Belderbos, 2003), but also negatively (Park and Park, 2000). On one hand, larger investing firms may find it easier to reach a withdrawal decision and give less weight to the survival of individual affiliates. However, a reverse argument also has appeal: larger firms have more financial or management resources and can exercise more patience for poorly performing affiliates. Parent size is the logarithm of parent firm sales in 1995. The analysis also controls for the presence of manufacturing affiliates established by other firms within the same vertical keiretsu (keiretsu affiliates in the country). The presence of other, vertical related, keiretsu affiliates, will allow replication of existing long-term transaction relationships and quality control and delivery systems (Head et al. 1995; Belderbos and Sleuwaegen, 1996), which may improve survival chances. Finally, the model also includes the main effect of non-platform affiliate taking the value one if the MNE operated another manufacturing affiliate than the focal affiliate in the country in 1995, and multinational portfolio correlation, as appropriate (only in those models where these variables are not the subject of the sample split).

We include several control variables at the affiliate level suggested to impact divestment probabilities by previous studies. Affiliate size (the logarithm of the number of employees of the affiliate in 1995) has been found to be positively associated with firm survival (Dunne et al, 1989; Mitchell, 1994; Mata et al, 1995). Studies have also shown that this positive relationship between firm size and survival applies to foreign affiliates (e.g. Mata and Portugal, 2000; Li, 1995). Affiliate age (the number of years the affiliate has been in operation until 1995) is included to capture that newly established affiliates suffer more from "liability of newness", while older affiliates have been able to improve their operations to adapt to host country conditions. Earlier evidence supports a positive relationship between firm age and firm or affiliate survival (e.g. Mitchell, 1994; Benito, 1997; Shaver 
et al, 1997). On the other hand, evidence has also been found for the presence of a "liability of adolescence" (Hannan, 1998), with the probability of survival decreasing with age over a range of years (Mata and Portugal, 2002; Li, 1995). To accommodate a more complex relationship between age and divestment, we include the loglinear and the squared loglinear term of affiliate age.

The entry mode of the affiliate is also likely to impact divestment probabilities. Most earlier studies suggest that foreign joint venture have a systematically higher probability of exit than wholly owned greenfield entries (e.g. Li, 1995; Hennart et al, 1998; Kim and Delios, 2003; Dhanaraj and Beamish, 2004). This has been related to failure to deal with management conflicts and cultural differences, but also to a learning perspective of joint ventures: foreign firms may withdraw from a joint venture and expand their wholly owned operations in the country once they have gained sufficient experience through the joint venture (Kogut, 1991; Yan and Zeng, 1999; Inkpen and Beamish, 1997). We include two dummy variables with wholly owned greenfield affiliates as reference group: majority owned $J V$ (dummy taking the value 1 if the affiliate is a joint venture in which the Japanese parent held a majority stake, 51-95 percent), and minority owned JV (dummy taking the value 1 if the affiliate is a joint venture in which the Japanese parent held a minority or 50 percent stake). ${ }^{15}$

In addition to the variables uncertainty and labor cost growth, the analysis includes a number of additional country control variables. We control for the potential impact of Japanese investor agglomeration in 1995 (the number of manufacturing affiliates in the electronics value chain in operation in the country in 1995, excluding those affiliates belonging to the parent firm of the focal affiliate). Foreign investor agglomeration may benefit affiliates in a country due to informational externalities, potential knowledge spillovers, externalities in the provision of specialized business services and intermediate inputs, or positive demand effects (e.g. Alcacer, 2007; Chang, 2005). In particular in case of Japanese firms, strong clustering patterns have been observed and attributed to greater externalities associated with co-location, due to the ease of communication and information exchange between Japanese companies, to the use of similar production techniques, labor training systems and labor pools, and to the common reliance on just-in-time (JIT) delivery systems and strict quality control requirements (Belderbos and Carree, 2002; Head et al., 1995; Chung and Song, 2004). 
Hence, the survival chances of Japanese affiliates may depend positively on the presence of a Japanese firm cluster in the country. Finally, we include the average logarithm of the FDI to GDP ratio during 1995 to 1998, as a broad measure of attractiveness of the countries which should also pick up regulatory and other changes that impact the attractiveness of countries to foreign investment. ${ }^{16}$ Summary statistics for the dependent variable, operational measures and control variables are provided in Table 1 and a correlation table is provided in Appendix A.

\section{INSERT TABLE 1}

\section{Empirical Results}

The results of the Probit model relating the probability of manufacturing affiliate divestment to the operational measures and control variables for all affiliates are presented in table 2. Model 1 only includes the control variables plus labor cost growth; model 2 adds macroeconomic uncertainty, and model 3 adds the interaction effect of these two variables testing the hysteresis hypothesis (H1). All three models are highly significant as indicated by the Chi-square test statistic, the loglikelihood ratio test shows that the fit of model 3 is significantly better than the fit of models 1 and 2 .

\section{INSERT TABLE 2}

In model 1 , labor cost growth has a positive and significant coefficient as expected, indicating that labor cost growth is an important driver of divestment decisions. Uncertainty has a negative coefficient but this coefficient is not significantly different from zero in model 2; in model 3 though, a 10 percent significance level of the coefficient suggests that uncertainty can generally reduce the probability of divestment. In model 3, the significantly negative interaction term between labor cost growth and uncertainty points at confirmation for Hypothesis 1, while at the same time the coefficient of the main effect of labor cost growth is more than doubled. In non-linear models such as the probit model, the sign and significance of the interaction effect is no definitive indication of the sign and 
significance of the moderating influence the interacted variables have on each other (e.g. Ai and Norton, 2003; Bowen and Wiersema, 2004; Hoetker, 2007). The moderating impact of macroeconomic uncertainty on labor cost growth (hysteresis) is defined as the impact of uncertainty on the marginal effect of labor cost growth on divestment. This cross derivative is a more complex expression which also depends on the estimated coefficients of the main effects and the estimated divestment probability for each observation. We report the estimated cross derivative and report results at the bottom of the tables. ${ }^{17}$ The cross derivative test confirms Hypothesis 1: the sign of the cross derivative is negative throughout, while it is significant (at the 10 percent level or higher) for 88 percent of the observations in the sample. The average coefficient of the cross derivative is estimated at -0.20 .

The two redundancy variables, non-platform affiliate and multinational portfolio correlation, have positive coefficients, of which the non-platform affiliate dummy variable is significant. A possible explanation is that it reflects a trend towards reorganization of manufacturing activities at the host country level in the wake of the Asian financial crisis, which has involved a greater concentration of manufacturing in core plants (Ernst, 1997). The estimated coefficients of the control variables are largely consistent with perceived theory and results in previous empirical studies. Parent size is negative and significant, indicating that larger firms are more resourceful and more likely to sustain affiliate investments. Parent firm patent intensity has the expected negative sign but the coefficient does not reach conventional significance levels; the same applies to affiliate size. Minority owned joint ventures, but not majority owned joint ventures, have a greater probability of divestment than wholly owned greenfield affiliates, consistent with the impact of equity stake on affiliate survival found in Dhanaraj and Beamish (2004). The estimated coefficient for the loglinear term of age is significant and positive, while the square term is negative but insignificant. The square term does reach statistical significance in model 3. Overall these results suggest that the probability of divestment increases with age, with a declining marginal impact. These results are more in line with the view that age can be a liability due to organizational rigidity (e.g. Hannan, 1998) than with an organizational learning view. Older affiliates may still rely on mature technologies or focus on markets with less growth potential, and in dynamic markets with rapid technological developments such as electronics, age is not 
necessarily an advantage ( $\mathrm{Li}, 1995)$. The number of keiretsu affiliates in the country has no significant impact on divestment decisions in any of the five models. The FDI to GDP ratio as an indicator of general attractiveness of host countries to foreign investments has the expected negative impact and is significant in the hypotheses testing model 3. Japanese investor agglomeration in 1995 has a negative sign and is highly significant, indicating important agglomeration benefits due to the clustering of Japanese firms.

\section{INSERT TABLE 3}

In Tables 3 and 4, results of split sample analyses are reported. The three models of Table 2 are re-run for each sample split. Table 3 shows results of three models for non-redundant plants (platform affiliates) versus host country redundant plants (non-platform affiliates). Table 4 shows the results for affiliates characterized by below median multinational portfolio correlation (low multinational portfolio redundant affiliates) versus affiliates with above median multinational portfolio correlation (high multinational portfolio redundant affiliates). Both sample splits are in relative balance: there are 594 platform affiliates (among which 50 are divested) and 484 non-platform affiliates (among which 47 divestments). The sample split for multinational portfolio redundancy is in balance by design (539 affiliates) with 51 divestments among multinational portfolio redundant affiliates and 46 among non-redundant affiliates.

Table 3 shows that the results of the full sample model are replicated for non redundant plants (platform affiliates). Labor cost growth has a significantly positive impact on divestment (model 1a), and this impact is significantly moderated by macroeconomic uncertainty in model 3a. The estimates of the cross-derivative confirm the hysteresis effect: the cross derivative is negative throughout and significant for 83 percent of the observations. The estimate of the cross derivative increases to -0.032 , up from -0.020 in the full sample model. For host country redundant (non-platform) affiliates, in contrast, the results are markedly different (models $1 \mathrm{~b}-3 \mathrm{~b}$ ). While there is a significant and positive effect of labor cost growth, this effect is not moderated by uncertainty as the interaction effect between labor cost growth and uncertainty is insignificant. The estimates of the cross derivative confirm the 
insignificance of the moderating impact of uncertainty. Together, these findings strongly support Hypothesis 2.

A similar set of results is obtained for the sample split according to multinational portfolio redundancy in Table 4. For low multinational portfolio redundant affiliates (affiliates with below median multinational portfolio correlation) the results of the full sample analyses are replicated (models 1a-3a). The positive impact of labor cost growth on divestment is significantly moderated by macroeconomic uncertainty. The estimates of the cross-derivative again confirm a strong hysteresis effect: the cross derivative is negative throughout with a higher estimated coefficient (-0.039) and is significant for 76 percent of the observations. In contrast, for high multinational portfolio redundant affiliates (models $1 b-3 b$ ), labor cost growth is not moderated by uncertainty, as seen from the insignificant interaction effect and the largely insignificant cross derivative. These findings strongly support Hypothesis 3.

\section{INSERT TABLE 4}

The interpretation of the magnitude of the hypothesized effects related to real options is not straightforward given the nonlinearity of the model and the interaction effects involved. To examine the impact of labor cost growth, macroeconomic uncertainty, and host country and multinational portfolio redundancy we calculated the predicted probability of divestment in a number of contrasting cases for the full sample and the four sub-samples. The results are presented in Table 5.

\section{INSERT TABLE 5}

A clear observation from these predicted divestment probabilities is that labor cost growth is a an important trigger of divestments. Under low labor cost growth, divestment probabilities are barely positive (in the range of $0.1-1.2$ percent points) and uncertainty has no appreciable impact on divestment. Divestment probabilities under high labor cost growth are substantial and reach up to 32 percent points in low uncertainty environments and 19 percent points in the full sample model (all 
affiliates). In the 'all affiliates' case, macroeconomic uncertainty completely neutralizes the divestment hazard, confirming a substantial role of real options and the investment hysteresis. The predicted probabilities also illustrate the effect of host country and multinational portfolio redundancy. Under low uncertainty and high labor cost growth, affiliates that are non-redundant from an options portfolio perspective (platform affiliates and affiliates with low multinational portfolio correlation) have the highest divestment probabilities (32 percent points) but these divestment probabilities are negligible under high macroeconomic uncertainty. If affiliates are redundant in one of these perspectives, base divestment probabilities are lower (10-13 percent points) but divestment probabilities are not affected by macroeconomic uncertainty. These results confirm that the magnitude of the effects of hysteresis and redundancy on divestment of foreign affiliates is substantial.

\section{Alternative specifications}

We examined a number of alternative specifications to check the consistency and robustness of the empirical findings. We tested whether results held up in a duration model (1995 - early 1999), where the analysis can examine the time variance in labor cost growth and macroeconomic uncertainty. We could include 48 divestments for which we could determine the exact year in which divestment took place. The results of a semi-parametric Cox proportional hazard model (reported in Appendix B) were highly consistent with the results of the probit models in Tables 2-4. Hysteresis was confirmed by significant interaction effects and cross derivatives between macroeconomic uncertainty and labor cost growth in the full sample model, as well as in the subsamples of platform affiliates and affiliates with below median multinational portfolio correlation. In subsamples for redundant affiliates (nonplatform affiliates and affiliates with above median multinational portfolio correlation) no significant interaction effects or cross derivatives were found.

We also confirmed the presence of a strong hysteresis effect for affiliates characterized by non-redundancy in both the host country and the multinational portfolio dimension. The interaction effect for this more restrictive subsample (400 affiliates, 38 divestments) was again significant and the cross derivative slightly higher (-0.041) than for the non-redundant subsamples in models in Tables 3 
and 4. The hysteresis effect was again absent for the subsample containing affiliates classified as redundant in any of the two dimensions.

We explored to what extent the degree of resource commitment and investment irreversibility impact hysteresis effects. Although we controlled for differences in divestment probabilities between joint ventures and greenfield affiliates, the hysteresis effect may differ according to the entry mode. In the literature there are different views on what entry mode serves as the best growth platform. Chang (1995) finds that effective growth platforms take the form of wholly owned affiliates focusing on core capabilities and foreign market learning. The literature on international joint ventures suggests that joint ventures are a means to provide learning opportunities and growth option value under internal and external uncertainty, while limiting resource commitments (e.g. Kogut, 1991; Cuypers and Martin, 2006; Li and Rugman, 2005). In the context of divestment decisions, one would expect the hysteresis effect to be stronger for entry modes with higher degrees of commitment and irreversibility, which are commonly features of greenfield affiliates. We explored the possible difference in hysteresis effects between greenfield affiliates and joint ventures and found the hysteresis effect to be stronger in the greenfield subsample (488 observations of which 36 divestments).

A related issue is a possible difference in the role of real options between types of divestments: plant closures on the one hand, and divestment through sale of the firm's equity stake in the affiliate on the other hand. Equity stake sales may indicate lower degrees of irreversibility and may be driven by other factors than adverse environmental conditions. Since the sample only contains 15 cases of equity stake sales, it is difficult with the data at hand to examine these potential differences in a systematic manner. Omitting the equity stake sale cases from the models in Tables 3 and 4 did not sharpen the results, but tended to marginally increase standard errors and reduce the magnitude of the coefficients of interest. Although this may be caused by a reduced variation resulting from selecting on the dependent variable, the results were not indicative that real option valuation is less important for divestments through equity stake sale in this setting.

\section{Conclusions and Discussion}


This paper developed a real options portfolio perspective on foreign investment and divestment. Growth or switch option value of the multinational firm's portfolio of foreign affiliates can be smaller than the sum of the option values of its individual foreign affiliates. Affiliates are sub-additive to the portfolio or (partially) redundant from an options portfolio perspective if the characteristics of their options overlap with those of other affiliates. This situation occurs if an affiliate shares a manufacturing platform role in the host country with other affiliates, or if macroeconomic conditions of the host country are highly correlated with those of other countries in which the multinational firm operates affiliates.

We analyzed foreign affiliate divestment decisions in a comprehensive sample of 1078 Japanese electronics manufacturing affiliates in operation in 1995 in nine Asian countries during the years leading up and into the Asian financial crisis (1995-1998). The empirical results gave strong support for a real options perspective on divestments. Affiliates established in host countries with adverse environmental changes (worsening labor cost conditions) were more likely to be divested, but this impact was reduced the greater the macroeconomic uncertainty in the country (as represented by real exchange rate volatility). This supported the notion that the valuation of growth and switch options in foreign affiliates under uncertainty can lead to investment 'hysteresis', a reluctance to divest manufacturing plants even under adverse circumstances. The portfolio perspective on the real option value of affiliates suggests that this hysteresis effect is weaker if the option value of the affiliate is subadditive to the portfolio. We distinguished redundancy at the host country level (multiple affiliates established in a host country by the same parent firm) and redundancy at the multinational affiliate portfolio level (the correlation in real exchange rate movements between the countries in which the multinational firm operates manufacturing affiliates). Empirical results strongly confirmed the presence of hysteresis effects theoretically associated with real option value for non-redundant affiliates, but showed no significant hysteresis effect for affiliates with high redundancy from a host country or multinational affiliate portfolio perspective. The findings were replicated in a duration (hazard) model examining the timing of divestments during the period 1995-1999 for a subset of the affiliates. 
The results support the notion that a configurations of country manufacturing platforms provides option value to the firm, by providing future growth options and switch options to adjust the distribution of manufacturing activities over locations under conditions of uncertainty (e.g. Kogut and Kulatilaka, 1994a;1994b). At the same time, the results confirm that multinational affiliate configurations have to be considered as a portfolio of options and that the characteristics of the portfolio affect option valuation and divestment probabilities of individual affiliates. This is akin to earlier findings on the real option valuation of technology alliances (Vassolo et al, 2004), where alliances with overlapping technological performance characteristics were found have higher termination rates. The results imply that affiliate divestment decisions should be considered in the context of wider multinational firm strategy and their position in international plant configurations, rather than as separate decisions, as has been the approach in most previous work on foreign divestments. The results provide an alternative explanation for previously reported limited effects of multinational presence on downside risk in multinationals. Early work by Reuer and Leiblein (2000) found no impact of multinationality on downside risk. Tong and Reuer (2007) found an inverted Ushape relationship between international plant dispersion and downside risk, and argue that with higher dispersion the marginal costs of coordination and utilization of switch options increases. Other moderators of affiliate portfolio option value that have been put forward are the cultural distance between countries in the portfolio hampering effective coordination (Tong and Reuer, 2007) and heterogeneities in the value of affiliate options related to entry mode and line of business (Tong, Reuer, and Peng, 2008). Our findings suggest that a plausible alternative explanation is that multinational firms differ in the degree of redundancy in their foreign affiliate portfolio and that this redundancy is likely to be greater for denser plant networks.

A limitation of this study is the restriction of our sample to Japanese affiliates in the (broadly defined) electronics sector in Asia, which reduces the scope for generalizations. The existence of extensive plant configurations of multinational firms spread over different countries, the importance of labor costs, and the 'footloose' nature of electronics assembly plants, are to an extent particular to assembly industries such as the electronics industry. Hence, it would be of interest to investigate to what extent similar systematic patterns of divestment occur in other industries and among affiliates 
owned by multinationals based in other countries. Second, our analysis of divestment only covered a time span of 4 years and was limited to the analysis of Asian affiliate configurations. This was a proper setting for our analysis, as this was a period of major uncertainty concerning exchange rate changes and market performance in Asia, during which divestments and relocation became a common phenomenon. A further longitudinal analysis of affiliates' survival probabilities by extending the time period of analysis and the cross-section dimension to the global level would however have important benefits. It would allow using survival models with a larger time dimension to investigate the dynamic impact of affiliate portfolios on divestment, and would provide further insights into the reaction of multinational firms to the Asian financial crisis and its aftermath. Extension to the global affiliate portfolio level would allow exploring whether affiliate portfolios are mostly regional in scope or conceived at the truly global level. Such analysis will generate more robust estimates of option valuations and redundancies within globally operating multinational firms. A related line of research would test the redundancy hypothesis in the context of downside risk performance or growth option valuations of multinational firms' affiliate portfolios, taking into account the correlation between macroeconomic fluctuations between plant locations in a comprehensive manner.

\section{References}

Adner, R., \& Levinthal, D. A. 2004. What is not a real option: Considering boundaries for the application of real options to business strategy. Academy of Management Review, 29: 74-85.

Ai, C.R. and E.C. Norton. 2003. Interaction Terms in logit and probit models, Economics Letters, 80 (1): 123-129.

Ai, C.R., H. Wang and E.C. Norton. 2004. Computing interaction effects and standard errors in logit and probit models, The Stata Journal, 4(2): 103-116.

Alcacer, J., 2006, Location Choices Across the Value Chain: How Activity and Capability Influence Collocation, Management Science, 52(10): 1457-1471.

Barkema, H.G. and O. Shvyrkov 2006. Does top management team diversity promote or hamper foreign expansion, Strategic Management Journal, 28(7), 663 - 680. 
Baum, J.A.C., T. Calabrese, B. Silverman. 2000. Don't go it alone: alliance networks and start-ups' performance in Canadian biotechnology. Strategic Management Journal. Special Issue, 21 (3): 267-294.

Belderbos R. 2003. Antidumping and foreign divestment: Japanese electronics multinationals in the EU. Review of World Economics, 139(1): 131-160.

Belderbos R, Capannelli G, Fukao K. 2001. Backward vertical linkages of foreign manufacturing affiliates: evidence from Japanese multinationals. World Development, 29(1): 189-208.

Belderbos R, Carree M. 2002. The location of Japanese investment in China: agglomeration effect, keiretsu and firm heterogeneity. Journal of Japanese and International Economies, 16(2): 194211.

Belderbos R, Sleuwaegen L. 1996. Japanese firms and the decision to invest abroad: industrial groups and regional core networks. Review of Economics and Statistics, 78(2): 214-220.

Belderbos R, and Sleuwaegen L. 2005. Competitive drivers and international plant configuration strategies: a product level test, Strategic Management Journal, 26(6): 577-593.

Belderbos. R., and J. Zou, 2007, On the Growth of Foreign Affiliates: Multinational Plant Networks, Joint ventures, and Flexibility, Journal of International Business Studies, 38(7): 1095-1112.

Benito GR. 1997. Divestment of foreign production operations. Applied Economics, 29(10): 13651377.

Boddewyn J. 1979. Foreign divestment: magnitude and factors. Journal of International Business Studies, 10(1): 21-27.

Bowen HP, Wiersema MF. 2004. Modeling limited dependent variables: methods and guidelines for researchers in strategic management. Research Methodology in Strategy and Management, Ketchen DJ, Bergh DD (eds). Elsevier: New York: 87-134.

Burt, R. S. 1992. Structural Holes: The Social Structure of Competition. Harvard University Press, Cambridge, MA.

Burt, R.S. 2004. Structural holes and good ideas. American Journal of Sociology, 110(2): 349-399. 
Cassiman, B. and R. Veugelers, 2006. In search of complementarity in innovation strategy: Internal $\mathrm{R} \& \mathrm{D}$, cooperation in $\mathrm{R} \& \mathrm{D}$ and external technology acquisition. Management Science, 52 (1): $68-82$

Campa, J., and L. Goldberg. 1999. "Investment, Pass-Through and Exchange Rates: A Cross-Country Comparison.” International Economic Review, vol. 40 (2): 287-314.

Caves RE. 1998. Industrial organization and new findings on the mobility and turnover of firms. Journal of Economic Literature, 36(4): 1947-1982.

Chang SJ, Park S. 2005. Types of firms generating network externalities and MNCs' co-location decisions. Strategic Management Journal, 26(7): 595-616.

Chang SJ. 1995. International expansion strategy of Japanese firms: capability building through sequential entry. Academy of Management Journal, 38(2): 383-407.

Chung W, Song JY. 2004. Sequential investment, firm motives, and agglomeration of Japanese electronics firms in the United States. Journal of Economics \& Management Strategy, 13(3): $539-560$.

Cleves, M.A., W.W. Gould, and R. G. Gutierrez. 2004. An Introduction to Survival Analysis using STATA, College Station (TX): STATA Press.

Cuypers, I.R.P. and Martin, X. (2006) 'What Makes and What Does Not Make a Real Option? A Study of International Joint Ventures’, Academy of Management Best Paper Proceedings.

Delios A, Beamish PW. 2001. Survival and profitability: the roles of experience and intangible assets in foreign subsidiary performance. Academy of Management Journal, 44 (5): 1028-1038.

Dhanaraj C, Beamish PW. 2004, Effect of equity ownership on the survival of international joint ventures. Strategic Management Journal, 25(3): 295-305.

Dunne T, Roberts MJ, Samuelson L. 1989. The growth and failure of U.S. manufacturing plants. Quarterly Journal of Economics, 104(4): 671-698.

Ernst, D. 1997. From Partial to Systemic Globalization: International Production Networks in the Electronics Industry. BRIE working paper 1-114, University of California at Berkeley. 
Folta, T.B., Johnson, D.R. and O'Brien, J.P. 2006 Uncertainty, irreversibility and the likelihood of entry: An empirical assessment of the option to defer. Journal of Economic Behavior and Organization, 61(3): 432-452.

Folta TB, O’Brien JP. 2004. Entry in the presence of dueling options. Strategic Management Journal, 25(2): $121-138$

Froot, K. A., J. C. Stein. 1991. Exchange rates and foreign direct investment: An imperfect capital market approach. Quarterly Journal of Economics, 105 (4): 191-1218.

Girotra, K., C. Terwiesch, K.T. Ulrich, 2007, Valuing R \& D Projects in a Portfolio: Evidence from the Pharmaceutical Industry, Management Science, 53: 1452-1466.

Gomes L, Ramaswamy K. 1999. An empirical examination of the form of the relationship between multinationality and performance. Journal of International Business Studies, 30(1) : 173-187.

Greene WH. 1997. Econometric Analysis, Englewood Cliffs, NJ, Prentice Hall.

Hannan MT. 1998. Rethinking age dependence in organizational mortality: logical formalizations. American Journal of Sociology, 104(1): 126-164.

Head K, Ries J, Swenson D. 1995. Agglomeration benefits and location choice: evidence from Japanese manufacturing investments in the United States. Journal of International Economics, 38(3/4): 223-247.

Hennart J-F, Kim DJ, Zeng M. 1998. The impact of joint venture status on the longevity of Japanese stakes in U.S. Manufacturing. Organization Science, 9(3): 382-395.

Hennart J-F. 1988. A transaction cost theory of equity joint ventures. Strategic Management Journal, 9(4): 361-374.

Hoetker, G., 2007, The Use of Logit and Probit Models in Strategic Management Research: Critical Issues. Strategic Management Journal, 28(4): 331-343.

Jovanovic B. 1982. Selection and the Evolution of Industry. Econometrica, 50(3): 649-670.

Inkpen AC, Beamish PW. 1997. Knowledge Bargaining Power and the Instability of Joint Ventures.Academy of Management Review, 22(1): 177-203. 
Kim TY, Delios A. 2003. Duality of Experiential Learning and Organizational Geography: Japanese Multinational Corporations in the People's Republic of China, 1979-2001, Paper presented at the 2003 Academy of Management Meetings, Seattle.

Kogut B, Chang SJ. 1996. Platform investments and volatile exchange rates: Japanese direct investment in US electronic industries. Review of Economics and Statistics, 78(2): 221-231.

Kogut B, Kulatilaka N. 1994a. Operational flexibility, global manufacturing, and the option value of a multinational network. Management Science, 40(1): 123-139.

Kogut B, Kulatilaka N. 1994b. Options thinking and platform investments: investing in opportunity, California Management Review. 36(2): 52-71

Kogut B. 1991. Joint ventures and the option to expand and acquire. Management Science, 37(1): 1934.

Kouvelis P, Axarloglou K, Sinha V. 2001. Exchange rates and the choices of ownership structure of production facilities in supplying foreign markets. Management Science, 47(8): 1063-1080.

Kulatilaka, N. and E.C. Perotti, 1998, Strategic Growth Options, Management Science, 40(1), 744758.

Li JT. 1995. Foreign entry and survival: effects of strategic choices on performance in international markets. Strategic Management Journal, 16(5): 348-362.

Li, J. and A. M. Rugman, 2005, Real Options and the Theory of Foreign Direct Investment, working paper, Kelley School of Business, Indiana University.

Lokshin B. Belderbos R., \& Carree M.. 2006. Complementarity in R\&D Cooperation Strategies, Review of Industrial Organization, 28(4): 401-426.

Mata J, Portugal P. 2000. Closure and divestment by foreign entrants: The impact of entry and postentry strategies. Strategic Management Journal, 21(5): 549-562.

Mata J, Portugal P. 2002. The survival of new domestic and foreign-owned firms. Strategic Management Journal, 23(4): 323-343.

Mata J, Portugal P, Guimaraes P. 1995. The Survival of New Plants: Start-Up Conditions and PostEntry Evolution. International Journal of Industrial Organization, 13(4): 459-481 
McGrath, R.G., 1997. A real options logic for initiating technology positioning investments, Academy of Management Review, 22(4): 974-996.

Milgrom, P., Roberts J. 1990. The economics of modern manufacturing: technology, strategy, and organization. American Economic Review, 80(3): 511-528.

Mitchell W. 1994. the Dynamics of Evolving Markets: the Effects of Business Sales and Age on Dissolutions and Divestitures. Administrative Science Quarterly, 39(4): 575-602.

Pan YG, Chi SK. 1999. Financial performance and survival of multinational corporations in China. Strategic Management Journal, 20(4): 359-374.

Park YR, Park SW. 2000. Determinants of FDI Survival: The Case of Korean Manufacturing Firms. Paper presented at the AIB conference in Phoenix, Arizona, November.

Pennings E, Sleuwaegen L. 2000. International Relocation: Firm and Industry Determinants. Economics Letters, 67(2): 182-184.

Rangan, S. 1998. Do Multinationals Operate Flexibly? Theory and Evidence, Journal of International Business Studies, 29(2): 217-237.

Reuer, J.J. and M.J Leiblein, 2000. Downside Risk Implications of Multinationality and International Joint Ventures, Academy of Management Journal, 43(2): 203-214.

Shaver JM, Mitchell W, Yeung B. 1997. The effect of own-firm and other-firm experience on foreign direct investment survival in the United States, 1987-92. Strategic Management Journal, 18(10): $811-824$

Shaver JM. 1998. Accounting for endogeneity when assessing strategy performance: does entry mode choice affect survival? Management Science, 44(4): 571-585.

Shaver JM, Flyer F. 2000. Agglomeration economies, firm heterogeneity, and foreign direct investment in the United States. Strategic Management Journal, 21(12): 1175-1193.

Song JY. 2002. Firm capability and technology ladders: sequential foreign direct investments of Japanese electronics firms in East Asia. Strategic Management Journal, 23(3): 191-201.

Tang CY, Tikoo S. 1999. Operating flexibility and market valuation of earnings. Strategic Management Journal, 18 (10): 811-824. 
Tong, T.W., \& Reuer, J.J. 2007. Real options in multinational corporations: Organizational challenges and risk implications. Journal of International Business Studies, 38(2): 215-230.

Tong, W.T, T.M. Alessandri, J.J Reuer, and A. Chintakananda. 2008. How Much Does Country Matter? An Analysis of Firms' Growth Options, Journal of International Business Studies, forthcoming.

Tong, T.W., Reuer, J.J. and Peng, M.W. 2008. 'International joint ventures and the value of growth options', Academy of Management Journal, forthcoming.

Toyo Keizai Inc. 1999. Kaigai Shinshutsu Kigyou Souran (Directory of Japanese Multinational Corporations). Tokyo: Toyo Keizai Inc.

Trigeorgis L. 1993. The nature of option interactions and the valuation of investments with multiple real options. Journal of Financial and Quantitative Analysis, 28(1): 1-22.

Vassolo, R. S., J. Anand, and T. B. Folta, 2004. Non-additivity in portfolios of exploration activities: A real options-based analysis of equity alliances in biotechnology. Strategic Management Journal, 25(11): 1045-1061.

Wooldridge, J.M. 2002, Econometric Analysis of Cross-Section and Panel data, Cambridge, MA: MIT press.

Yan AM, Zeng M. 1999. International Joint Venture Instability: a Critique of Previous Research, a Reconceptualization, and Directions For Future Research. Journal of International Business

Studies, 30(2): 395-412.

Zaheer S, Mosakowki E. 1997. The dynamics of the liability of foreignness: a global study of survival in financial services. Strategic Management Journal, 18(6): 439-464. 
Table 1. Descriptive statistics and definitions of dependent and explanatory variables

\begin{tabular}{|c|c|c|c|}
\hline Name & Description & Mean & Stdev \\
\hline Divestment & $\begin{array}{l}\text { Binary variable denoting if the affiliate is divested or not } \\
\text { between early } 1995 \text { and early } 1999\end{array}$ & 0.09 & 0.29 \\
\hline Labor cost increase & $\begin{array}{l}\text { Percentage growth in annual wages (expressed in Yen) for } \\
\text { manufacturing workers in the host country's electronics } \\
\text { industry between } 1995 \text { and } 1998\end{array}$ & 0.40 & 0.33 \\
\hline Uncertainty & $\begin{array}{l}\text { Coefficient of variation of the monthly real exchange rate } \\
\text { of local currency against the Yen during 1995-1998 }\end{array}$ & 0.12 & 0.10 \\
\hline $\begin{array}{l}\text { Non-platform } \\
\text { affiliate }\end{array}$ & $\begin{array}{l}\text { Dummy taking the value } 1 \text { if the affiliate shares the } \\
\text { country platform role with other affiliates: the parent firm } \\
\text { operates multiple manufacturing affiliates in the country in } \\
1995\end{array}$ & 0.45 & 0.50 \\
\hline $\begin{array}{l}\text { Multinational } \\
\text { portfolio correlation }\end{array}$ & $\begin{array}{l}\text { Sum of correlations (1995-1998) of the monthly real } \\
\text { exchange rate of the country of the affiliate and the } \\
\text { monthly real exchange rates of the other countries in which } \\
\text { the parent firm operated manufacturing affiliates }\end{array}$ & 1.48 & 1.40 \\
\hline $\begin{array}{l}\text { Parent firm Patent } \\
\text { intensity }\end{array}$ & $\begin{array}{l}\text { Number of US patents granted to the parent firm during } \\
1993-1999 \text { times } 1000 \text {, divided by parent sales in } 1995\end{array}$ & 0.89 & 1.50 \\
\hline Parent size & Logarithm of parent firm sales (million Yen) in 1995 & 11.13 & 2.36 \\
\hline Affiliate size & $\begin{array}{l}\text { Logarithm of the number of employees of the affiliate in } \\
1995\end{array}$ & 5.65 & 1.41 \\
\hline Affiliate age & $\begin{array}{l}\text { Logarithm of the number of years the affiliate has been in } \\
\text { operation until } 1995\end{array}$ & 1.93 & 0.91 \\
\hline Affiliate age $^{2}$ & Affiliate age squared & 4.56 & 3.38 \\
\hline Majority owned JV & $\begin{array}{l}\text { Dummy taking the value } 1 \text { if the affiliate is a joint venture } \\
\text { in which the Japanese parent holds a majority stake ( } 51 \text { - } \\
95 \text { percent) }\end{array}$ & 0.24 & 0.43 \\
\hline Minority owned JV & $\begin{array}{l}\text { Dummy taking the value } 1 \text { if the affiliate is a joint venture } \\
\text { in which the Japanese parent holds a minority or } 50 \\
\text { percent stake }\end{array}$ & 0.30 & 0.46 \\
\hline Keiretsu affiliates & $\begin{array}{l}\text { Number of affiliates in the country established by member } \\
\text { firms of the same vertical keiretsu }\end{array}$ & 4.17 & 6.74 \\
\hline $\begin{array}{l}\text { Japanese investor } \\
\text { agglomeration }\end{array}$ & $\begin{array}{l}\text { Number of Japanese manufacturing affiliates in the } \\
\text { electronics value chain in operation in the country in 1995, } \\
\text { excluding those affiliates belonging to the parent firm of } \\
\text { the focal affiliate }\end{array}$ & $\begin{array}{l}202.2 \\
7\end{array}$ & 86.81 \\
\hline FDI to GDP ratio & $\begin{array}{l}\text { Logarithm of the ratio of average FDI inflow and average } \\
\text { GDP of the country (95-98 average) }\end{array}$ & -3.50 & 1.05 \\
\hline
\end{tabular}


Table 2: Logit model of the Probability of Japanese Affiliate Divestment in Asia 1995-1998

\begin{tabular}{|c|c|c|c|}
\hline & Model 1 & Model 2 & Model 3 \\
\hline \multirow[t]{2}{*}{ Labor cost growth } & 1,2597 & 1,0155 & 1,9838 \\
\hline & {$[0.3578]^{\star \star *}$} & {$[0.3865]^{* * *}$} & {$[0.5858]^{* \star *}$} \\
\hline \multirow[t]{2}{*}{ Macroeconomic uncertainty } & & $-0,0134$ & $-0,0168$ \\
\hline & & {$[0.0120]$} & [0.0103] \\
\hline \multirow[t]{2}{*}{ Labor cost growth * macroeconomic uncertainty (1) } & & & $-0,0703$ \\
\hline & & & {$[0.0274]^{* * *}$} \\
\hline \multirow[t]{2}{*}{ non-platform affiliate } & 0,3553 & 0,3589 & 0,3583 \\
\hline & {$[0.1495]^{\star \star}$} & {$[0.1476]^{\star \star}$} & {$[0.1462]^{\star \star}$} \\
\hline \multirow[t]{2}{*}{ Multinational portfolio correlation } & 0,1533 & 0,1408 & 0,1401 \\
\hline & {$[0.0656]^{\star \star}$} & {$[0.0703]^{\star \star}$} & {$[0.0715]^{\star \star}$} \\
\hline \multirow[t]{2}{*}{ Parent size } & $-0,202$ & $-0,2012$ & $-0,2014$ \\
\hline & {$[0.0558]^{* * *}$} & {$[0.0564]^{* * *}$} & {$[0.0558]^{* * *}$} \\
\hline \multirow[t]{2}{*}{ Parent firm patent intensity } & $-0,0578$ & $-0,0564$ & $-0,0552$ \\
\hline & [0.0482] & {$[0.0473]$} & [0.0482] \\
\hline \multirow[t]{2}{*}{ Affiliate size } & $-0,0717$ & $-0,0603$ & $-0,0414$ \\
\hline & {$[0.0577]$} & {$[0.0598]$} & {$[0.0606]$} \\
\hline \multirow[t]{2}{*}{ affiliate age } & 0,4919 & 0,4608 & 0,545 \\
\hline & {$[0.2697]^{*}$} & {$[0.2704]^{\star}$} & {$[0.2772]^{\star \star}$} \\
\hline \multirow[t]{2}{*}{ affiliate age square } & $-0,1048$ & $-0,1041$ & $-0,1307$ \\
\hline & {$[0.0686]$} & {$[0.0678]$} & {$[0.0710]^{*}$} \\
\hline \multirow[t]{2}{*}{ Majority owned JV } & $-0,1196$ & $-0,1145$ & $-0,1246$ \\
\hline & [0.1799] & {$[0.1808]$} & {$[0.1527]^{\star *}$} \\
\hline \multirow[t]{2}{*}{ Minority owned JV } & 0,3057 & 0,3216 & 0,3255 \\
\hline & {$[0.1513]^{\star *}$} & {$[0.1528]^{\star *}$} & {$[0.1806]$} \\
\hline \multirow[t]{2}{*}{ Keiretsu affiliates in the country } & 0,0198 & 0,0204 & 0,0194 \\
\hline & {$[0.0155]$} & {$[0.0153]$} & [0.0152] \\
\hline \multirow[t]{2}{*}{ Japanese investor agglomeration } & $-0,004$ & $-0,004$ & $-0,0041$ \\
\hline & {$[0.0013]^{* * *}$} & {$[0.0013]^{* * *}$} & {$[0.0013]^{* * *}$} \\
\hline \multirow[t]{2}{*}{ FDI to GDP ratio } & $-0,1208$ & $-0,1004$ & $-0,1537$ \\
\hline & {$[0.0805]$} & {$[0.0775]$} & {$[0.0794]^{\star}$} \\
\hline \multirow[t]{2}{*}{ Constant } & 0,0473 & 0,3607 & $-0,0593$ \\
\hline & [0.6942] & {$[0.6752]$} & {$[0.6826]$} \\
\hline Observations & 1078 & 1078 & 1078 \\
\hline Number of divestments & 97 & 97 & 97 \\
\hline Log Likelihood & $-282,60$ & $-281,72$ & $-279,77$ \\
\hline Chi-2 & $91,45^{\star \star *}$ & $95,85^{\star * *}$ & $105,6^{\star \star *}$ \\
\hline \multicolumn{4}{|l|}{ Cross-derivative (1) } \\
\hline \multicolumn{3}{|l|}{ Mean value } & $-0,020$ \\
\hline \multicolumn{3}{|l|}{$\%$ of negative value (of which significant) } & $100(88)$ \\
\hline \multicolumn{4}{|l|}{ LR tests } \\
\hline \multicolumn{2}{|l|}{ Chi-2 Model 2,3 vs. Model 1} & 1.76 & $5,67^{*}$ \\
\hline \multicolumn{2}{|l|}{ Chi-2 Model 3 vs. Model 2} & & $3.91^{\star *}$ \\
\hline
\end{tabular}

Notes: Robust standard errors, clustered by parent firm, in parentheses; *, **, *** indicate significant at the 10, 5, 1 percent level, respectively (two-tailed test). Significance cross derivative is evaluated at the 10 percent level. 
Table 3. Logit models of the Probability of Japanese Affiliate Divestment in Asia 1995-1998 Host country redundant affiliates vs. non-redundant affiliates

\begin{tabular}{|c|c|c|c|c|c|c|}
\hline & \multicolumn{6}{|c|}{ Host country redundancy } \\
\hline & no & no & no & yes & yes & yes \\
\hline & Model 1a & Model $2 a$ & Model 3a & Model $1 \mathrm{~b}$ & Model $2 b$ & Model 3b \\
\hline \multirow[t]{2}{*}{ Labor cost growth } & 1,2537 & 0,84 & 2,319 & 1,7084 & 1,9458 & 1,7355 \\
\hline & {$[0.4687]^{* * *}$} & {$[0.4840]^{\star}$} & {$[0.8953]^{* * *}$} & {$[0.6277]^{\star * *}$} & {$[0.7611]^{\star *}$} & {$[0.8417]^{\star *}$} \\
\hline \multirow[t]{2}{*}{ Macroeconomic uncertainty } & & $-0,0244$ & $-0,0314$ & & 0,0093 & 0,0099 \\
\hline & & [0.0170] & {$[0.0124]^{\star *}$} & & [0.0137] & [0.0148] \\
\hline \multirow[t]{2}{*}{ Labor cost growth * macroeconomic uncertainty (1) } & & & $-0,1098$ & & & 0,0146 \\
\hline & & & {$[0.0441]^{\star *}$} & & & {$[0.0459]$} \\
\hline \multirow[t]{2}{*}{ Multinational portfolio correlation } & 0,0671 & 0,0523 & 0,0411 & 0,2657 & 0,2787 & 0,2787 \\
\hline & {$[0.0928]$} & [0.0953] & {$[0.1016]$} & {$[0.1052]^{\star *}$} & {$[0.1068]^{* * *}$} & {$[0.1065]^{\star \star *}$} \\
\hline \multirow[t]{2}{*}{ Parent size } & $-0,1236$ & $-0,1295$ & $-0,138$ & $-0,2974$ & $-0,3008$ & $-0,3019$ \\
\hline & {$[0.0665]^{*}$} & {$[0.0661]^{*}$} & {$[0.0670]^{\star *}$} & {$[0.0818]^{\star * *}$} & {$[0.0822]^{\star * *}$} & {$[0.0829]^{\star * *}$} \\
\hline \multirow[t]{2}{*}{ Parent firm patent intensity } & $-0,1$ & $-0,1$ & $-0,1009$ & 0,0236 & 0,0252 & 0,0247 \\
\hline & {$[0.0742]$} & {$[0.0746]$} & [0.0753] & {$[0.0512]$} & {$[0.0525]$} & {$[0.0522]$} \\
\hline \multirow[t]{2}{*}{ affiliate age } & $-0,02$ & 0,0063 & 0,0303 & $-0,1713$ & $-0,1802$ & $-0,186$ \\
\hline & {$[0.0650]$} & {$[0.0681]$} & [0.0702] & {$[0.1032]^{*}$} & {$[0.1074]^{*}$} & {$[0.1058]^{*}$} \\
\hline \multirow[t]{2}{*}{ affiliate age square } & 0,1409 & 0,0674 & 0,191 & 1,2275 & 1,2608 & 1,2452 \\
\hline & [0.3084] & [0.3081] & [0.3227] & {$[0.3955]^{\star * *}$} & {$[0.3848]^{\star * *}$} & {$[0.3919]^{\star * *}$} \\
\hline \multirow[t]{2}{*}{ Square of log of affiliate age } & $-0,0393$ & $-0,0387$ & $-0,0786$ & $-0,2436$ & $-0,2484$ & $-0,2433$ \\
\hline & {$[0.0814]$} & {$[0.0806]$} & [0.0858] & {$[0.1073]^{\star *}$} & {$[0.1060]^{\star *}$} & {$[0.1092]^{\star *}$} \\
\hline \multirow[t]{2}{*}{ Majority owned JV } & $-0,196$ & $-0,1821$ & $-0,1944$ & 0,0064 & 0,011 & 0,0137 \\
\hline & {$[0.2116]$} & [0.1953] & [0.2128] & {$[0.2827]$} & {$[0.2830]$} & {$[0.2341]$} \\
\hline \multirow[t]{2}{*}{ Minority owned JV } & 0,1257 & 0,1437 & 0,1696 & 0,4706 & 0,4552 & 0,4571 \\
\hline & {$[0.1930]$} & [0.2122] & [0.1984] & {$[0.2327]^{\star *}$} & {$[0.2334]^{*}$} & {$[0.2846]^{*}$} \\
\hline \multirow[t]{2}{*}{ Keiretsu affiliates in the country } & 0,0343 & 0,0336 & 0,0335 & 0,0229 & 0,0226 & 0,0231 \\
\hline & {$[0.0226]$} & {$[0.0229]$} & {$[0.0241]$} & {$[0.0196]$} & {$[0.0196]$} & {$[0.0200]$} \\
\hline \multirow[t]{2}{*}{ Japanese investor agglomeration } & $-0,0037$ & $-0,0041$ & $-0,0045$ & $-0,0047$ & $-0,005$ & $-0,005$ \\
\hline & {$[0.0015]^{\star *}$} & {$[0.0015]^{\star * *}$} & {$[0.0016]^{* * *}$} & {$[0.0024]^{*}$} & {$[0.0024]^{* *}$} & {$[0.0024]^{\star *}$} \\
\hline \multirow[t]{2}{*}{ FDI to GDP ratio } & $-0,1933$ & $-0,1555$ & $-0,2252$ & $-0,1027$ & $-0,1211$ & $-0,1079$ \\
\hline & {$[0.1075]^{*}$} & [0.1012] & {$[0.1011]^{\star *}$} & {$[0.1377]$} & {$[0.1396]$} & {$[0.1314]$} \\
\hline \multirow[t]{2}{*}{ Constant } & $-0,7306$ & $-0,0316$ & $-0,4607$ & 0,8312 & 0,6324 & 0,7581 \\
\hline & {$[0.8667]$} & {$[0.8847]$} & {$[0.9069]$} & {$[1.0202]$} & {$[1.0194]$} & {$[1.0286]$} \\
\hline Observations & 594 & 594 & 594 & 484 & 484 & 484 \\
\hline Number of divestments & 50 & 50 & 50 & 47 & 47 & 47 \\
\hline Log Likelihood & $-159,20$ & $-157,50$ & $-154,77$ & $-114,68$ & $-114,53$ & $-114,50$ \\
\hline Chi-2 & $41,24^{* * *}$ & $39,07^{* * *}$ & $54,16^{* * *}$ & $120,98^{* * *}$ & $122,72^{\star * *}$ & $122,83^{* * *}$ \\
\hline \multicolumn{7}{|l|}{ Cross-derivative (1) } \\
\hline Mean value & & & $-0,032$ & & & 0,006 \\
\hline$\%$ of negative value (of which significant) & & & $100(83)$ & & & $2(0)$ \\
\hline$\%$ of positive value (of which significant) & & & $0(0)$ & & & $98(0)$ \\
\hline \multicolumn{7}{|l|}{ LR tests } \\
\hline Chi- 2 Model 2, 3 vs. Model 1 & & $3.40^{*}$ & $8.86^{\star \star}$ & & 0.31 & 0.37 \\
\hline Chi-2 Model 3 vs. Model 2 & & & $5.46^{\star *}$ & & & 0.06 \\
\hline
\end{tabular}

Notes: Robust standard errors, clustered by parent firm, in parentheses; *, **, *** indicate significant at the 10, 5, 1 percent level, respectively (two-tailed test). Significance of cross derivative is evaluated at the 10 percent level. Host country redundant affiliates are non-platform affiliates. 
Table 4. Logit models of the Probability of Japanese Affiliate Divestment in Asia 1995-1998: Affiliates with high multinational portfolio redundancy vs. affiliates with low multinational portfolio redundancy

\begin{tabular}{|c|c|c|c|c|c|c|}
\hline & \multicolumn{6}{|c|}{ Multinational portfolio redundancy } \\
\hline & low & low & low & high & high & high \\
\hline & Model 1a & Model $2 \mathrm{a}$ & Model 3a & Model $1 b$ & Model 2b & Model 3b \\
\hline Labor cost growth & $\begin{array}{c}1,3792 \\
{[0.5370]^{\star *}}\end{array}$ & $\begin{array}{c}1,1837 \\
{[0.5562]^{\star *}}\end{array}$ & $\begin{array}{c}2,8932 \\
{[0.9153]^{\star * \star}}\end{array}$ & $\begin{array}{c}1,1659 \\
{[0.5525]^{\star *}}\end{array}$ & $\begin{array}{c}0,8742 \\
{[0.5905]}\end{array}$ & $\begin{array}{c}1,324 \\
{[0.7904]^{*}}\end{array}$ \\
\hline Macroeconomic uncertainty & & $\begin{array}{c}-0,0093 \\
{[0.0139]}\end{array}$ & $\begin{array}{c}-0,021 \\
{[0.0126]^{*}}\end{array}$ & & $\begin{array}{c}-0,0214 \\
{[0.0175]}\end{array}$ & $\begin{array}{c}-0,0181 \\
{[0.0131]}\end{array}$ \\
\hline Labor cost growth * macroeconomic uncertainty (1) & & & $\begin{array}{c}-0,1219 \\
{[0.0454]^{* * *}}\end{array}$ & & & $\begin{array}{c}-0,0332 \\
{[0.0342]}\end{array}$ \\
\hline Non-platform affiliate & $\begin{array}{c}0,2069 \\
{[0.2048]}\end{array}$ & $\begin{array}{c}0,2146 \\
{[0.2048]}\end{array}$ & $\begin{array}{c}0,1818 \\
{[0.2043]}\end{array}$ & $\begin{array}{c}0,521 \\
{[0.2410]^{\star \star}}\end{array}$ & $\begin{array}{c}0,5159 \\
{[0.2369]^{\star *}}\end{array}$ & $\begin{array}{c}0,525 \\
{[0.2346]^{\star *}}\end{array}$ \\
\hline Multinational portfolio correlation & $\begin{array}{c}0,0954 \\
{[0.2300]}\end{array}$ & $\begin{array}{c}0,0857 \\
{[0.2301]}\end{array}$ & $\begin{array}{c}0,0387 \\
{[0.2348]}\end{array}$ & $\begin{array}{c}0,1635 \\
{[0.1061]}\end{array}$ & $\begin{array}{c}0,1412 \\
{[0.1130]}\end{array}$ & $\begin{array}{c}0,1471 \\
{[0.1131]}\end{array}$ \\
\hline Parent size & $\begin{array}{c}-0,2006 \\
{[0.0658]^{\star \star \star}}\end{array}$ & $\begin{array}{c}-0,2017 \\
{[0.0662]^{\star \star \star}}\end{array}$ & $\begin{array}{c}-0,1912 \\
{[0.0649]^{\star \star \star}}\end{array}$ & $\begin{array}{c}-0,2127 \\
{[0.0796]^{\star \star *}}\end{array}$ & $\begin{array}{c}-0,2073 \\
{[0.0812]^{\star *}}\end{array}$ & $\begin{array}{c}-0,211 \\
{[0.0798]^{\star \star \star}}\end{array}$ \\
\hline Parent firm patent intensity & $\begin{array}{c}-0,1179 \\
{[0.0957]}\end{array}$ & $\begin{array}{c}-0,114 \\
{[0.0947]}\end{array}$ & $\begin{array}{c}-0,1145 \\
{[0.0999]}\end{array}$ & $\begin{array}{c}-0,0273 \\
{[0.0713]}\end{array}$ & $\begin{array}{c}-0,0277 \\
{[0.0692]}\end{array}$ & $\begin{array}{c}-0,0272 \\
{[0.0690]}\end{array}$ \\
\hline Affiliate size & $\begin{array}{l}-0,0746 \\
{[0.0757]}\end{array}$ & $\begin{array}{c}-0,064 \\
{[0.0780]}\end{array}$ & $\begin{array}{l}-0,0303 \\
{[0.0807]}\end{array}$ & $\begin{array}{l}-0,0735 \\
{[0.0822]}\end{array}$ & $\begin{array}{l}-0,0608 \\
{[0.0842]}\end{array}$ & $\begin{array}{l}-0,0535 \\
{[0.0846]}\end{array}$ \\
\hline affiliate age & $\begin{array}{c}0,2757 \\
{[0.3308]}\end{array}$ & $\begin{array}{c}0,253 \\
{[0.3343]}\end{array}$ & $\begin{array}{c}0,3955 \\
{[0.3461]}\end{array}$ & $\begin{array}{c}0,8307 \\
{[0.5253]}\end{array}$ & $\begin{array}{c}0,7783 \\
{[0.5169]}\end{array}$ & $\begin{array}{c}0,8139 \\
{[0.5157]}\end{array}$ \\
\hline affiliate age square & $\begin{array}{l}-0,0375 \\
{[0.0971]}\end{array}$ & $\begin{array}{l}-0,0379 \\
{[0.0971]}\end{array}$ & $\begin{array}{l}-0,0863 \\
{[0.1022]}\end{array}$ & $\begin{array}{l}-0,1843 \\
{[0.1152]}\end{array}$ & $\begin{array}{l}-0,1798 \\
{[0.1124]}\end{array}$ & $\begin{array}{c}-0,1904 \\
{[0.1126]^{\star}}\end{array}$ \\
\hline Majority owned JV & $\begin{array}{c}-0,1554 \\
{[0.2158]}\end{array}$ & $\begin{array}{c}-0,1519 \\
{[0.2153]}\end{array}$ & $\begin{array}{c}-0,1894 \\
{[0.2086]}\end{array}$ & $\begin{array}{c}-0,023 \\
{[0.2122]}\end{array}$ & $\begin{array}{c}-0,0168 \\
{[0.2568]}\end{array}$ & $\begin{array}{c}-0,016 \\
{[0.2088]}\end{array}$ \\
\hline Minority owned JV & $\begin{array}{c}0,1754 \\
{[0.2057]}\end{array}$ & $\begin{array}{c}0,1828 \\
{[0.2054]}\end{array}$ & $\begin{array}{c}0,1653 \\
{[0.2176]}\end{array}$ & $\begin{array}{c}0,4544 \\
{[0.2557]^{\star *}}\end{array}$ & $\begin{array}{c}0,4938 \\
{[0.2081]^{\star *}}\end{array}$ & $\begin{array}{c}0,4961 \\
{[0.2566]^{\star *}}\end{array}$ \\
\hline Keiretsu affiliates in the country & $\begin{array}{c}0,0307 \\
{[0.0170]^{*}}\end{array}$ & $\begin{array}{c}0,031 \\
{[0.0170]^{\star}}\end{array}$ & $\begin{array}{c}0,0291 \\
{[0.0176]^{*}}\end{array}$ & $\begin{array}{c}0,0062 \\
{[0.0221]}\end{array}$ & $\begin{array}{c}0,0061 \\
{[0.0219]}\end{array}$ & $\begin{array}{c}0,0057 \\
{[0.0218]}\end{array}$ \\
\hline Japanese investor agglomeration & $\begin{array}{c}-0,0044 \\
{[0.0017]^{\star * \star}}\end{array}$ & $\begin{array}{c}-0,0044 \\
{[0.0016]^{\star \star \star}}\end{array}$ & $\begin{array}{c}-0,005 \\
{[0.0017]^{\star \star \star}}\end{array}$ & $\begin{array}{c}-0,003 \\
{[0.0021]}\end{array}$ & $\begin{array}{l}-0,0028 \\
{[0.0021]}\end{array}$ & $\begin{array}{l}-0,0028 \\
{[0.0021]}\end{array}$ \\
\hline FDI to GDP ratio & $\begin{array}{l}-0,1958 \\
{[0.1200]}\end{array}$ & $\begin{array}{c}-0,1777 \\
{[0.1178]}\end{array}$ & $\begin{array}{c}-0,2757 \\
{[0.1195]^{\star \star}}\end{array}$ & $\begin{array}{l}-0,0504 \\
{[0.1034]}\end{array}$ & $\begin{array}{l}-0,0303 \\
{[0.0971]}\end{array}$ & $\begin{array}{l}-0,0516 \\
{[0.0982]}\end{array}$ \\
\hline Constant & $\begin{array}{c}0,0452 \\
{[0.9530]}\end{array}$ & $\begin{array}{c}0,3005 \\
{[1.0206]}\end{array}$ & $\begin{array}{l}-0,4047 \\
{[0.9943]}\end{array}$ & $\begin{array}{l}-0,2016 \\
{[1.0832]}\end{array}$ & $\begin{array}{c}0,175 \\
{[1.0171]}\end{array}$ & $\begin{array}{c}-0,038 \\
{[1.0936]}\end{array}$ \\
\hline Observations & 539 & 539 & 539 & 539 & 539 & 539 \\
\hline Number of divestments & 51 & 51 & 51 & 46 & 46 & 46 \\
\hline Log Likelihood & $-146,72$ & $-146,46$ & $-143,51$ & $-132,47$ & $-131,78$ & $-131,64$ \\
\hline Chi-2 & $48,7^{\star * \star}$ & $48,81^{* * *}$ & $60,12^{\star \star *}$ & $62,99^{* * *}$ & $71,78^{\star * *}$ & $96,94^{* * *}$ \\
\hline Cross-derivative (1) & & & & & & \\
\hline Mean value & & & $-0,039$ & & & $-0,009$ \\
\hline$\%$ of negative value (of which significant) & & & $100(76)$ & & & $99.8(7)$ \\
\hline$\%$ of positive value (of which significant) & & & $0(0)$ & & & $0.2(0)$ \\
\hline LR tests & & & & & & \\
\hline Model 2, 3 vs. Model 1 & & 0.51 & $6.41^{*}$ & & 1.37 & 1.66 \\
\hline Model 3 vs. Model 2 & & & $5.90^{* *}$ & & & 0.29 \\
\hline
\end{tabular}

Notes: Robust standard errors, clustered by parent firm, in parentheses; *, **, *** indicate significant at the 10,5,1 percent level, respectively (two-tailed test). Significance of cross derivatives is evaluated at the 10 percent level. High multinational portfolio redundant affiliates are affiliates with above mean multinational portfolio correlation. 
Table 5. Predicted divestment probabilities (\%) under labor cost growth, uncertainty, and redundancy

\begin{tabular}{lll}
\hline All affiliates & High labor cost growth & Low labor cost growth \\
low uncertainty & 19.1 & 0.8 \\
high uncertainty & 0.0 & 0.9 \\
& & \\
$\begin{array}{l}\text { Host country redundant affiliates } \\
\text { low uncertainty }\end{array}$ & 10.1 & 0.1 \\
high uncertainty & 10.1 & 0.1 \\
Host country non-redundant & & \\
$\begin{array}{l}\text { affiliates } \\
\text { low uncertainty }\end{array}$ & 31.9 & \\
high uncertainty & 0.0 & 1.2 \\
& & 0.6 \\
High multinational portfolio redundant affiliates & \\
low uncertainty & 13.1 & 0.7 \\
high uncertainty & 13.1 & 0.7 \\
$\begin{array}{l}\text { Low multinational portfolio redundant affiliates } \\
\text { low uncertainty } \\
\text { high uncertainty }\end{array}$ & 0,0 & \\
\end{tabular}

Notes: Calculations with control variables taken in the sample mean, and with significant coefficients of uncertainty and labor cost growth; high (low) uncertainty is the highest (lowest) real exchange rate volatility among the nine Asian countries; high (low) labor cost growth is the highest (lowest) increase in real labor costs among these countries. 


\section{Appendix A: Correlation Table}

\begin{tabular}{|c|c|c|c|c|c|c|c|c|c|c|c|c|c|c|c|}
\hline & 1 & 2 & 3 & 4 & 5 & 6 & 7 & 8 & 9 & 10 & 11 & 12 & 13 & 14 & 15 \\
\hline 1 Divestment & $\overline{1,00}$ & & & & & & & & & & & & & & \\
\hline 2 Labor cost growth & 0,02 & 1,00 & & & & & & & & & & & & & \\
\hline 3 Macroeconomic uncertainty & $-0,07$ & $-0,56$ & 1,00 & & & & & & & & & & & & \\
\hline 4 non-platform affiliate & 0,02 & 0,12 & $-0,04$ & 1,00 & & & & & & & & & & & \\
\hline 5 Multinational portfolio correlation & 0,01 & $-0,18$ & $-0,03$ & 0,26 & 1,00 & & & & & & & & & & \\
\hline 6 Parent size & $-0,16$ & $-0,05$ & 0,04 & 0,49 & 0,44 & 1,00 & & & & & & & & & \\
\hline 7 Parent firm patent intensity & $-0,08$ & 0,00 & $-0,01$ & 0,15 & 0,14 & 0,38 & 1,00 & & & & & & & & \\
\hline 8 Affiliate size & $-0,11$ & $-0,11$ & 0,10 & 0,23 & 0,23 & 0,42 & 0,18 & 1,00 & & & & & & & \\
\hline 9 affiliate age & 0,06 & $-0,27$ & $-0,13$ & $-0,03$ & 0,27 & 0,10 & 0,05 & 0,31 & 1,00 & & & & & & \\
\hline 10 affiliate age square & 0,05 & $-0,23$ & $-0,14$ & $-0,02$ & 0,27 & 0,12 & 0,05 & 0,29 & 0,96 & 1,00 & & & & & \\
\hline 11 Majority owned JV & $-0,07$ & $-0,01$ & 0,01 & 0,03 & $-0,05$ & 0,03 & $-0,05$ & 0,00 & $-0,07$ & $-0,04$ & 1,00 & & & & \\
\hline 12 Minority owned JV & 0,12 & $-0,08$ & 0,05 & 0,08 & 0,05 & 0,00 & $-0,06$ & $-0,11$ & 0,04 & 0,06 & $-0,38$ & 1,00 & & & \\
\hline 13 Keiretsu affiliates in the country & $-0,04$ & 0,19 & $-0,05$ & 0,37 & 0,16 & 0,51 & 0,02 & 0,14 & $-0,16$ & $-0,14$ & 0,08 & 0,15 & 1,00 & & \\
\hline 14 Japanese investor agglomeration & $-0,07$ & 0,77 & $-0,38$ & 0,18 & $-0,22$ & 0,01 & $-0,03$ & $-0,03$ & $-0,44$ & $-0,42$ & 0,06 & $-0,01$ & 0,28 & 1,00 & \\
\hline 15 FDI to GDP ratio & $-0,01$ & 0,63 & $-0,18$ & 0,12 & $-0,11$ & 0,01 & $-0,03$ & 0,07 & $-0,28$ & $-0,31$ & $-0,02$ & $-0,17$ & 0,16 & 0,42 & 1,00 \\
\hline
\end{tabular}




\section{Appendix B: Cox Proportional Hazard Model of Affiliate Divestments, 1995-1999}

We used the semi-parametric Cox proportional hazard model to examine the impact of hysteresis and redundancy on the timing of divestments. We have 1027 affiliates in early 1995 (the year we take as the onset of risk) of which 48 are divested in the period up to March 1999. The dependent variable is the duration of the spell until divestment and takes values between 1 (for divestments in 1995) and 4.3 (divestments within the first 3 months of 1999). ${ }^{18}$ As divestments can occur early or late in a year, we relate the hazard of divestment in a year to average labor cost growth and macroeconomic uncertainty in that year and the preceding year. Platform affiliate status and multinational portfolio correlation values for affiliate are also time-varying, as they may change during the period due to new affiliate investments and divestments.

The empirical results of a full sample hazard model, and split sample models with respect to affiliate platform status (host country redundancy, models 2 and 3) and multinational portfolio correlation (low versus high network redundancy, models 4 and 5) are presented in Table B.1. Model 1 (full sample) reconfirms the presence of hysteresis: the interaction effect between uncertainty and labor cost growth is significantly negative. Since the coefficients of the Cox model show the effect of a unit changes in independent variables on the proportional change in the single period divestment hazard $(\exp (\mathrm{xb}))$ and lend themselves to a direct interpretation as an elasticity (e.g. Cleves et al, 2004; Wooldridge, 2002), we also calculated the cross effect of uncertainty on the elasticity of the hazard with respect to labor cost growth. ${ }^{19}$ Analysis of this cross derivative expressed as an elasticity shows that the moderating impact is negative for all observations and significant for 46 percent of the observations. Splitting the sample between host country non-redundant (platform) affiliates (model 2) and host country redundant (nonplatform) affiliates (model 3) shows a significant hysteresis effect for non-redundant affiliates, but no such significant effect for redundant affiliates. The estimated cross-derivative for the non-redundant sample is negative for 78 percent of observations and significant for 46 percent of observations, while the cases of positive cross derivatives are never statistically significant. For redundant affiliates, the cross derivative is 
Real options and foreign affiliate divestment

never significant. This provides confirmation for the presence of a hysteresis effect among non-redundant affiliates. Similar results are obtained for the sub-sample of affiliates that are non-redundant from a multinational portfolio perspective (affiliates with a multinational portfolio correlation below the median of 0.38 , in model 4 ): a significant interaction term and a negative cross derivative (throughout), which is significant for 70 percent of observations. For multinational portfolio redundant affiliates (model 5), no significant hysteresis effect is found. 
Real options and foreign affiliate divestment

Table B1: Cox Proportional Hazard Model of Japanese Affiliate Divestment in Asia, 1995-1998

\begin{tabular}{|c|c|c|c|c|c|}
\hline & \multirow[t]{2}{*}{ All affliates } & \multicolumn{2}{|c|}{ Host country redundancy } & \multicolumn{2}{|c|}{ Multinational portfolio redundancy } \\
\hline & & No & Yes & Low & High \\
\hline & Model 1 & Model2 & Model3 & Model4 & Model 5 \\
\hline \multirow[t]{2}{*}{ Labor cost growth } & 2,5445 & 5,053 & 1,5524 & 4,3824 & $-1,2661$ \\
\hline & {$[1.3578]^{*}$} & {$[1.4847]^{* \star *}$} & {$[1.6066]$} & {$[1.9279]^{\star *}$} & [2.1655] \\
\hline \multirow[t]{2}{*}{ Macroeconomic uncertainty } & $-0,1081$ & $-0,2555$ & $-0,0141$ & $-0,1243$ & $-0,0671$ \\
\hline & {$[0.0641]^{*}$} & {$[0.0608]^{* * *}$} & {$[0.0638]$} & {$[0.0997]$} & [0.0862] \\
\hline \multirow[t]{2}{*}{ Labor cost growth * macroeconomic uncertainty (1) } & $-0,2387$ & $-0,601$ & $-0,0457$ & $-0,3006$ & $-0,0581$ \\
\hline & {$[0.0933]^{\star \star}$} & {$[0.0968]^{* * *}$} & {$[0.1195]$} & {$[0.1083]^{\star \star *}$} & {$[0.1823]$} \\
\hline \multirow[t]{2}{*}{ non-platform affiliate } & 1,0048 & & & 0,9454 & 1,0707 \\
\hline & {$[0.3156]^{\star * \star}$} & & & {$[0.3956]^{\star \star}$} & {$[0.5668]^{*}$} \\
\hline \multirow[t]{2}{*}{ Multinational portfolio correlation } & 0,2023 & $-0,3585$ & 0,9931 & 0,0475 & $-0,0717$ \\
\hline & {$[0.2721]$} & [0.2699] & {$[0.4281]^{\star *}$} & {$[0.3048]$} & [0.8424] \\
\hline \multirow[t]{2}{*}{ Parent size } & $-0,4114$ & $-0,4271$ & $-0,4696$ & $-0,6143$ & $-0,1797$ \\
\hline & {$[0.1150]^{* * *}$} & {$[0.1910]^{\star \star}$} & {$[0.1764]^{\star \star *}$} & {$[0.1369]^{\star * *}$} & {$[0.1594]$} \\
\hline \multirow[t]{2}{*}{ Parent firm patent intensity } & $-0,0634$ & 0,0167 & $-0,1941$ & 0,0075 & $-0,2504$ \\
\hline & {$[0.1638]$} & {$[0.1233]$} & {$[0.3208]$} & {$[0.1811]$} & {$[0.3100]$} \\
\hline \multirow[t]{2}{*}{ Affiliate size } & 0,0122 & 0,349 & $-0,2881$ & 0,0343 & $-0,0487$ \\
\hline & [0.1433] & [0.2602] & [0.1871] & {$[0.2049]$} & {$[0.2009]$} \\
\hline \multirow[t]{2}{*}{ affiliate age } & 0,8713 & 1,2923 & 0,4727 & 1,6736 & 0,4577 \\
\hline & {$[0.5455]$} & {$[1.0816]$} & {$[0.6348]$} & {$[0.7993]^{\star \star}$} & [0.9383] \\
\hline \multirow[t]{2}{*}{ affiliate age square } & $-0,1646$ & $-0,3845$ & 0,0411 & $-0,4175$ & $-0,0329$ \\
\hline & {$[0.1558]$} & {$[0.2586]$} & {$[0.2180]$} & {$[0.2426]^{*}$} & {$[0.2409]$} \\
\hline \multirow[t]{2}{*}{ Minority owned JV } & 0,3785 & $-0,0839$ & 0,282 & $-0,1604$ & 1,0153 \\
\hline & {$[0.4088]$} & {$[0.5622]$} & {$[0.5712]$} & {$[0.5468]$} & {$[0.6997]$} \\
\hline \multirow[t]{2}{*}{ Majority owned JV } & 0,1205 & $-0,0366$ & 0,5836 & 0,1572 & $-0,0965$ \\
\hline & {$[0.4490]$} & [0.5587] & [0.6869] & {$[0.4981]$} & {$[0.5541]^{*}$} \\
\hline \multirow[t]{2}{*}{ Keiretsu affiliates in the country } & 0,0511 & 0,0788 & 0,0398 & 0,1057 & $-0,0588$ \\
\hline & {$[0.0424]$} & {$[0.0926]$} & {$[0.0486]$} & {$[0.0464]^{\star *}$} & {$[0.0656]$} \\
\hline \multirow[t]{2}{*}{ Japanese investor agglomeration } & $-0,0019$ & $-0,0037$ & $-0,0001$ & $-0,0028$ & $-0,0046$ \\
\hline & {$[0.0011]^{\star}$} & {$[0.0024]$} & {$[0.0011]$} & {$[0.0017]^{*}$} & {$[0.0025]^{*}$} \\
\hline \multirow[t]{2}{*}{ FDI to GDP ratio } & $-0,0641$ & $-0,1338$ & $-0,1074$ & $-0,2798$ & 0,1979 \\
\hline & {$[0.1442]$} & {$[0.1902]$} & {$[0.1957]$} & {$[0.2167]$} & {$[0.2007]$} \\
\hline No of subjects & 1027 & 627 & 496 & 758 & 703 \\
\hline No. of divestments & 48 & 21 & 27 & 28 & 20 \\
\hline Log pseudolikelihood & $-303,94$ & $-118,29$ & $-142,2$ & $-156,78$ & $-112,23$ \\
\hline Wald Chi-2 & $106,21^{\star * \star}$ & $165,77^{\star \star \star}$ & $98,02^{* * *}$ & $133,95^{\star \star \star}$ & $42,07^{* * *}$ \\
\hline \multicolumn{6}{|l|}{ Cross-derivative (1) } \\
\hline Mean value & $-0,294$ & $-0,480$ & $-0,072$ & $-0,601$ & 0,081 \\
\hline$\%$ of negative value (of which significant) & $100(46)$ & $78(46)$ & $100(0)$ & $100(70)$ & $2(0)$ \\
\hline$\%$ of positive value (of which significant) & $0(0)$ & $22(0)$ & $0(0)$ & $0(0)$ & $98(0)$ \\
\hline
\end{tabular}

Notes: Robust standard errors, clustered by parent firm, in parentheses; *, **, *** indicate significant at the 10, 5, 1 percent level, respectively (two-tailed test). Significance cross derivative is evaluated at the 10 percent level. High multinational portfolio redundant affiliates are affiliates with above mean multinational portfolio correlation. Host country redundant affiliates are non-platform affiliates. 


\section{Endnotes}

${ }^{1}$ Contributions to the literature on survival of foreign affiliates include Boddewyn (1979), Li (1995), Shaver (1998), Shaver et al (1997), Zaheer and Mosakowski (1997), Delios and Beamish (2001), Mata and Portugal (2000), Pennings and Sleuwaegen (2000). Theses studies have not examined divestments from a real options perspective and have tended to pay less attention to the potential impact of the multinational plant configurations, often due to the single country setting of the empirical analysis. Belderbos and Sleuwaegen (2005) examined the determinants of global plant configurations but neither examined the role of real options logic. The industrial organization literature has a longer history of examining exit decisions of domestic firms (e.g. Jovanovic, 1982; Dunne et al., 1989; Caves, 1998).

${ }^{2}$ Chang (1995) finds that such follow up investments tend to be more diversified in nature, whereas the initial investments are more strongly based on core competitive advantages exploited in greenfield affiliates of the investing firms. Other contributions (e.g. Kogut, 1991) emphasize the role of international joint ventures as growth platforms.

${ }^{3}$ Recent studies have explored the application of the real options approach to international joint ventures in particular, suggesting that the type of uncertainty (exogenous vs. endogenous to the venture) is an important moderator of the impact of the option value of joint ventures on multinational firms' entry mode decisions (Li and Rugman, 2005; Cuypers and Martin, 2006). In this paper we deal with exogenous (macroeconomic) uncertainty, which has a straightforward interpretation in real options valuation (Adner and Levinthal, 2004). We also abstract from the threat of pre-emption of the exercise of real options by rival firms (Kulatilaka and Perotti, 1998; Folta and O’Brien, 2004).

${ }^{4}$ Folta et al (2006) analyze of the role of irreversibility and uncertainty in detail in the context of entry decisions.

${ }^{5}$ The formal valuation of correlated options in a portfolio is highly complex (e.g. Trigeorgis, 1993).

${ }^{6}$ Milgrom and Roberts (1990) use the terms submodularity (sub-additivity) and supermodularity (superadditivity) in the context of combinations of organisational practices affecting organisational objective 
functions. For recent applications to R\&D (collaboration) strategies and their impact on innovative performance, see for instance Cassiman and Veugelers (2006) and Lokshin et al. (2006).

${ }^{7}$ Real option redundancy in a portfolio perspective bares some resemblance to the redundancy concept in social network theory (Burt, 1992; 2004), which has been applied in the context of technology alliances (e.g. Baum et al, 2000). Here the value of a specific alliance in the firm's network is smaller (the alliance is redundant) if the knowledge obtained through the alliance is also (partly) available through the firm's other alliances. Whereas within the social network perspective the informational ties and flows between alliance partners are essential, the options portfolio perspective does not presume that affiliates have concurrent ties within a network structure. An operational tie between any two affiliates will only potentially arise, if the multinational firm decides to exercise the switch options within the portfolio and transfer manufacturing activities between countries. Both redundancy concepts suggest that it is the variety within the portfolio or network that underlies their valuation.

${ }^{8}$ The coverage is much broader, in particular for smaller and privately held firms, than the coverage of the often-used directory compiled by Toyo Keizai Inc. (e.g. Delios and Beamish, 2001).

${ }^{9}$ We find highly consistent results for the hazard model with a more limited number of divestments. This is in line with Shaver and Flyer (2000), who also report very comparable results of duration and probit models in their analysis of divestments by foreign affiliates in the US.

${ }^{10}$ Another candidate for adverse macroeconomic circumstances, decline in host country market demand, is less relevant in export oriented industries such as the electronics sector. We experimented with a hybrid measure of adverse circumstances by combining the impact of labor cost growth and market demand, and found qualitatively similar but statistically weaker results.

${ }^{11}$ This compares to the approach in Vassolo et al. (2004), where portfolio redundancy is measured as the degree of overlap in technology profiles between the alliances in the firm's portfolio.

${ }^{12}$ The exchange rate policies and movements have varied considerably across countries during the period. The Philippine currency has been freely floating and the Singaporean dollar has been on a free float under 
a 'monitoring' regime (with undisclosed band). Several other currencies (those of South Korea, Indonesia, Thailand, Taiwan) were subject to a managed float up to the financial crisis in 1997, after which a free float was adopted by the first three countries. Malaysia, in contrast pegged its currency to the dollar in 1998 after experiencing difficulties managing the float of the ringgit. Hong Kong and China are the only countries that maintained a peg to the dollar throughout the period.

${ }^{13}$ No negative correlations over the period 1995-1998 were observed among the nine Asian countries. In the yearly analysis of the duration model (appendix B) negative correlations are observed; results are highly consistent with the results of the probit model.

${ }^{14}$ Different definitions of multinational portfolio redundancy (e.g. splitting at the mean) gave similar results. A split around the median has the advantage that empirical results are less likely to be affected by different sample sizes (e.g. Hoetker, 2007).

${ }^{15}$ Since acquisitions are almost absent in the sample (5 affiliates), we group these together with the reference category of greenfield affiliates.

${ }^{16} \mathrm{We}$ also attempted to control for demand factors by including a measure of host country electronics market growth but this variable was not significant in any model, probably due to the export orientation of electronics plants in Asia.

${ }^{17}$ Cross derivatives were estimated with the inteff command in STATA due to Ai et al. (2004). The cross derivative is $[\beta 12-(\beta 1+\beta 12 \times 2)(\beta 2+\beta 12 \times 1) X \beta] \varphi$, where $\varphi$ is the normal density function.

${ }^{18}$ Taking the year of affiliate establishment as the onset of risk does not change the empirical results in an appreciable manner. The divestments included in the sample took place in 1995 (4), 1996 (10), 1997 (9), 1998 (22) and 1999 (3). We cannot determine whether the larger number of divestments included in 1998 is a fully representative feature of the sample: since our main source of information on divestments is a survey in 1999, the precise year of recent divestments is more likely to be reported than the year of divestments early in the period. 
Real options and foreign affiliate divestment

${ }^{19}$ Coefficients and standard errors were calculated with the predictnl command in STATA as $1 / \mathrm{p}[\mathrm{p} \beta 12-$ $\mathrm{p}(\beta 1+\beta 12 \mathrm{x} 2)(\beta 2+\beta 12 \mathrm{x} 1)]$, with $\mathrm{p}(\exp (\mathrm{xb}))$ the predicted hazard. 